\title{
Installation of Deep Groundwater Wells as Solution to Water Resources Problem in Panggang Subsystem, Gunungsewu Karst Area, Indonesia
}

\author{
Indra Agus Riyanto ${ }^{1,2, *}$, Ahmad Cahyadi ${ }^{1,3}$, Dwi Sismoyo ${ }^{4}$, Muhammad Naufal ${ }^{1,3,}{ }^{*}$, Fajri Ramadhan $^{1,3}$, Margaretha \\ Widyastuti ${ }^{1,3}$, and Tjahyo Nugroho Adji ${ }^{1,3}$ \\ ${ }^{1}$ Karst Research Group, Faculty of Geography, Universitas Gadjah Mada, Yogyakarta - Indonesia \\ ${ }^{2}$ Master Program on Planning and Management of Coastal Area and Watershed, Faculty of Geography, Universitas Gadjah Mada, \\ Yogyakarta - Indonesia \\ ${ }^{3}$ Department of Environmental Geography, Faculty of Geography, Universitas Gadjah Mada, Yogyakarta - Indonesia \\ ${ }^{4}$ Department of Soil Science, Faculty of Agriculture, Universitas Gadjah Mada, Yogyakarta - Indonesia
}

\begin{abstract}
The karst area in Panggang Subsystem, Gunungsewu has specific hydrogeological properties, including predominant epikarst springs with minimal discharge in dry seasons. Since this situation inevitably leads to drought, the installation of deep wells to extract water from deep aquifers is proposed as an alternative solution to water provision. This study determined the location of these wells using general geological and geomorphological surveys, followed by analyzing the results of geophysical measurements. The results showed potential aquifers in the sand layer of tertiary volcanic aquifers under the limestone formation that makes the karst region. Although three borewells were constructed at three different points, only two of them succeeded and are ready for use to meet the clean water needs of the population at the research site.
\end{abstract}

Keywords: Panggang Subsystem; Deep Groundwater Wells; Alternative Water Resources

\section{Background}

Gunungsewu Karst, located in Gunungkidul Regency, the Special Region of Yogyakarta, Indonesia, has six main hydrogeological subsystems, namely Panggang, Ponjong, Bribin-Baron, Pracimantoro-Wuryantoro, Donoharjo-Pringkuku, and Sadeng Subsystems [1] (Figure 1). Panggang Subsystem is one of the hydrogeology blocks that have serious problems related to water resources, particularly limited clean water quantity $[2,3]$. Aside from the absence of a sizeable underground system, the lack of water resources is caused by the hydrogeological conditions of the area where springs with relatively small discharge prevail and sparsely spread along the outer boundary of the limestone formation [4]. Consequently, the central part of Panggang Subsystem has little water resources.

Panggang Block has low groundwater potential [5]. This hydrogeological subsystem has a moderately productive aquifer whose groundwater flow is limited to fissure, fracture zone, and solution channels [6]. Some of the springs in this subsystem are categorized as epikarst spring with low potential, while the rest is contact springs, emerging due to contact with the underlying tertiary volcanic rock [3]. The hydrograph analysis of Guntur, one of the springs in this location, revealed that the karstification of an epikarst spring is at undeveloped level $[7,8]$. The springs in Panggang Block create a pattern of concentration in the north and south of this subsystem [2]. Furthermore, the underground river system and karst passage fall into the category of undeveloped [4].

Drought in Gunungsewu Karst Area [9], especially in Panggang Subsystem [10], has now become a severe problem that needs to be addressed immediately. Part of this subsystem has gained access to clean water from the supply network organized by the Regional Drinking Water Company (Perusahaan Daerah Air Minum, PDAM) - sourced from Ngobaran Underground River in Baron Subsystem, east of Panggang Subsystem [11]. However, because this network does not reach every settlement in Panggang Subsystem, the drought management still prioritizes clean water delivery to the unreached population by tanker trucks. Although this solution seems to alleviate water scarcity during drought seasons, it has become less efficient and more costly every year.

Another water source alternative that can be utilized by the people in Panggang Block is deep groundwater. Previous research has shown that below the limestone layer in this subsystem are tertiary volcanic aquifers that have great groundwater potentialfor extraction [3]. This study aimed to continue the

\footnotetext{
* Corresponding author: indra.agus.r@gmail.com, adji@geo.ugm.ac.id
} 
preliminary geophysical research with validation by wells installation.
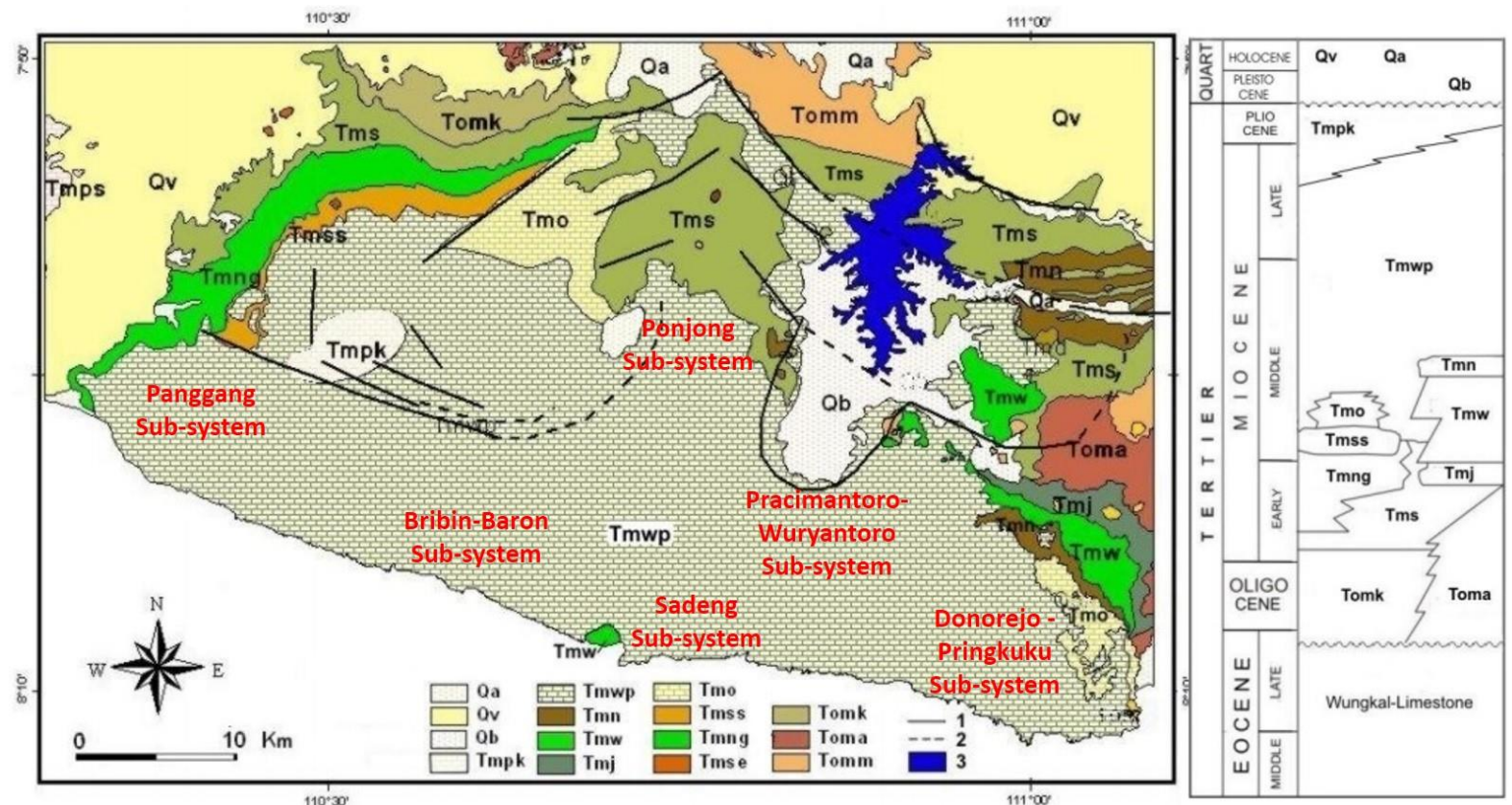

Fig. 1. The Hydrogeological System of Gunungsewu Karst Area [1 with modifications]

\section{Methodology}

\subsection{Tools and Materials}

The tools used in this study included geological sonar for geophysical tests, well-drilling machine for borehole construction, measuring tape to measure material thickness, cameras for documentation, hydrogeological maps, Indonesian topographical maps, and geological maps to determine the location of bore wells, as well as ArcGIS software to map the suitable places for these bore wells. The research materials referred to any literature or publications related to geological characteristics and previous geophysical analysis in the study area.

\subsection{Determining the Location of Well Drilling}

Potential sites or points for the installation of the deep wells were determined from the results of the geophysical analysis using geological sonar. The site selection considered discharge potential, productive aquifer depth, and the characteristics of the location, including the possibility of water delivery by gravity, the ease of distribution to the community, and the accessibility of the drilling site. In this case, accessibility pertains to the mobilization of drilling machinery and equipment.

\subsection{Study Area}

The study area is located in Panggang Subsystem-part of Gunungsewu Karst-specifically in Dringgo Hamlet, Girijati Village, Purwosari District, Gunungkidul Regency, and the Special Region of Yogyakarta. It lies in 427500-428500 $\mathrm{mE}$ and $911650-911550 \mathrm{mN}$ (Figure 2 ). The rainfall in this subsystem ranges from 2,200 to $2,400 \mathrm{~mm} /$ year [12]. The western and northern parts of the study site are abutted by the Baturagung Escarpment that separates them from Bantul Graben. This subsystem is bordered by the Indian Ocean to the south and the Baron-Bribin Subsystem to the east.

Referring to the United States Department of Agriculture (USDA) Soil Taxonomy, the soils in the study area are dominated by Typic Eutropepts, Typic Tropaquepts, Fluventic Eutropepts, and Lithic Ustropepts [13]. The physiography of Panggang Block comprises varying elevations from 100-400 masl and slopes ranging from $8^{\circ}-35^{\circ}$, which are classified into undulating, hilly, and very hilly or steep. Panggang Subsystem has a population of 49,541 people [14] that are distributed in two districts, namely Purwosari and Panggang.

Panggang Subsystem lies in Wonosari-Punung Formation (Tmwp) with dominant neogenous limestone deposited during the Middle Miocene and Upper Pliocene. It is composed of reef limestone dominated by rudstone, packstones, and framestones [1]. The lower part of Wonosari-Punung formation is volcanic rock. Volcanic rocks that underlie Panggang Subsystem are from two ancient volcanoes, namely Parangtritis and Mangunan [15, 16, 17, 18, 19], enabling the development of aquifers that are potential for clean water source [3]. 


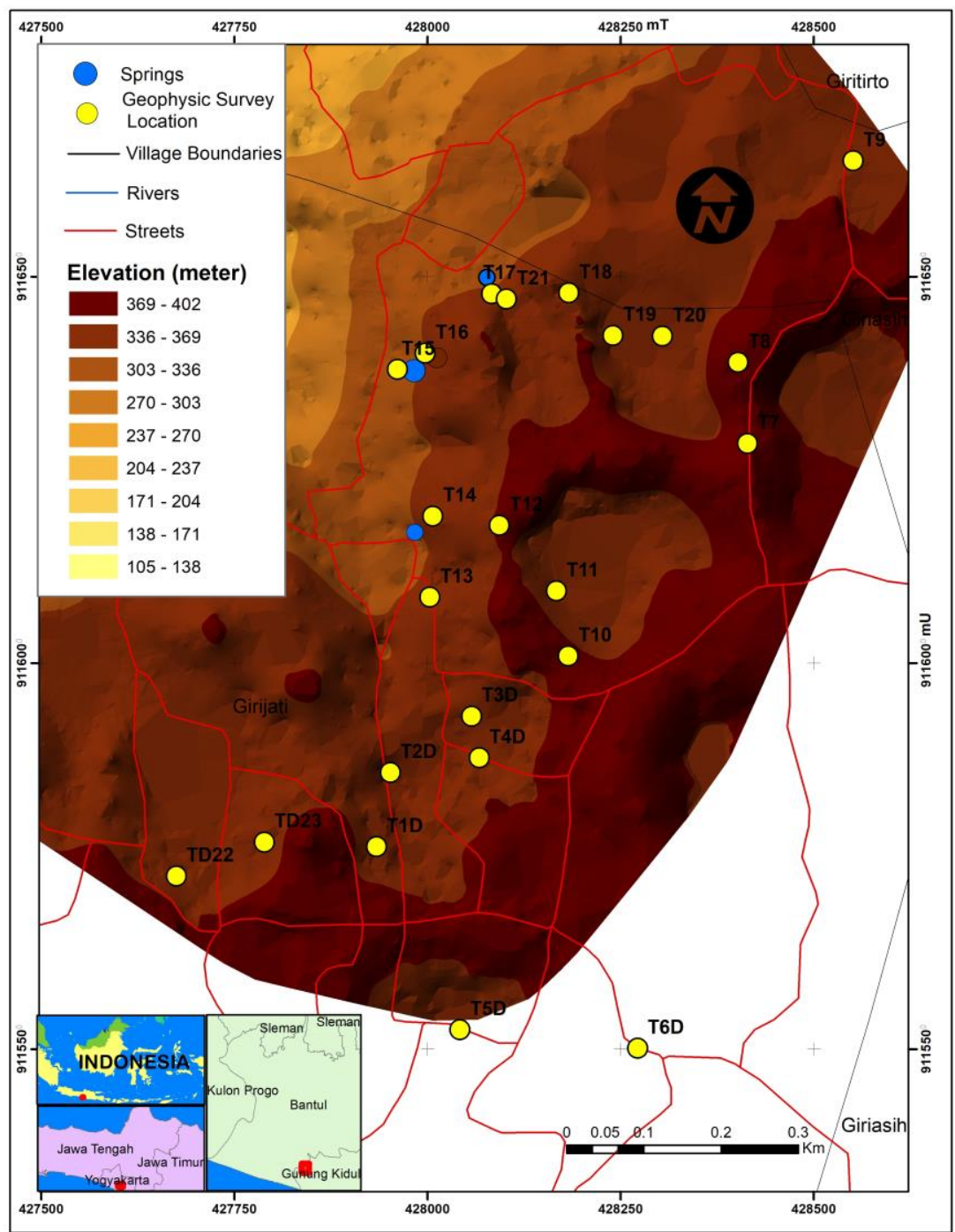

Fig. 2. The Locations of Geological Sonar Measurement Location

\section{Result and Discussion}

\subsection{Well Drilling Points}

The drilling sites were selected based on several considerations, namely groundwater discharge potential, accessibility, distribution of extractable water, and the status of the land. For instance, T6D bore well has the most significant discharge and the land is part of village government properties. Meanwhile, T2D and T13 are on the roadside (accessible) with moderate groundwater discharge and limestone materials that are not as thick as T6D. However, these two points were first situated in a privately-owned land, and to proceed with the drilling, $1 \mathrm{x} 1 \mathrm{~m}^{2}$ parcel of this land had to be purchased. Except for this disadvantage, both points are composed of bedded limestones, meaning that the installation of the wells did not need to drill through hard materials like it did in T6D (massive reef limestones). Another downside of T6D is in the fact that it is located in a karst basin or valley, which means that not only this bore well is difficult to reach but lifting water from its position in the valley to the top would also require a lot of energy.

\subsection{Drilling Procedures in Selected Sites}

The drilling at T6D was financed by a private sector, and according to the results of the geophysical survey, it had to be $100 \mathrm{~m}$ deep. Using dowsing rods, this study revealed that $\mathrm{T} 6 \mathrm{D}$ was right in the path of underground river flow. The subsequent validation with very low frequency (VLF) electromagnetic method at T6D $(60 \mathrm{~m}$ deep borehole; Figure 3) confirmed that the rods reading was accurate. The material at T6D consists of reef limestone (0-25 m), limestone and gravel (25-27 m), and marl $(27-60 \mathrm{~m})$. The drilling of bore well at T6D stopped at a depth of $60 \mathrm{~m}$ because the drilling equipment could not penetrate the thick and hard layer of massive limestones. 


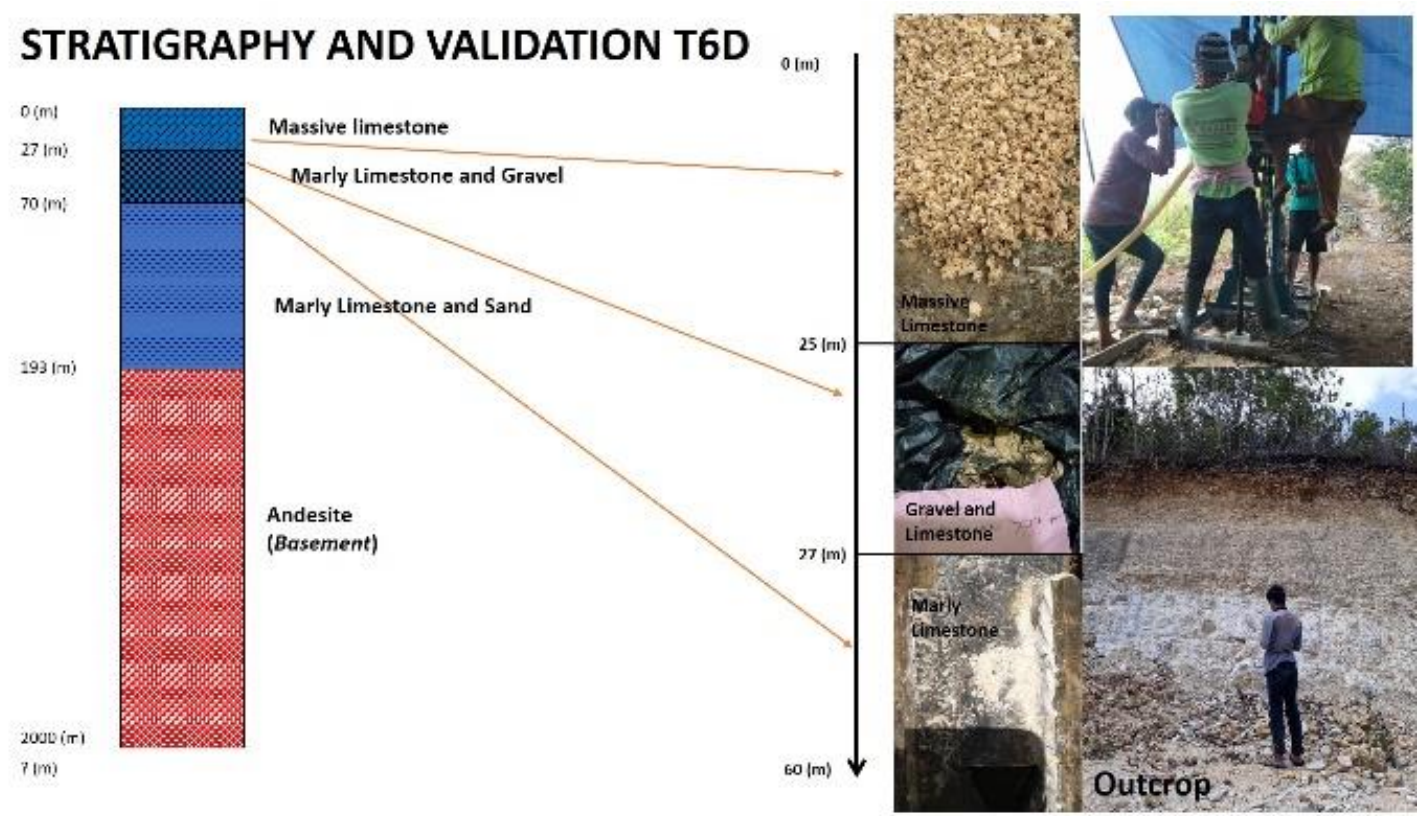

Fig. 3. Stratigraphy of T6D

Moreover, it used a lot of water that quickly ran out because this borehole went through the secondary porosity system, which has numerous cavities or passages and fractures, causing the water to disappear rapidly. Using up more than 50 tank trucks of water, drilling up to $60 \mathrm{~m}$ deep was costly. The estimate says that water in sand materials can be detected at a depth of $>70 \mathrm{~m}$ with a discharge of $27 \mathrm{~m}^{3} /$ hour. At this rate, the constructed bore well can potentially meet the needs of 500 households or approximately 2,000 people.

T2D is a substitute for the borehole at T6D where the drilling had to stop. T2D does not have dominant limestone and is a depositional zone of materials that guarantee its water potential. Validation with VLF at this point (60m deep borehole; Figure 4) affirmed the results of previous geophysical research. The materials at T2D consist of massive limestone and topsoil (0-8 m), marly limestone, gravel, and sand $(8-45 \mathrm{~m})$, and sandy clay $(45-60 \mathrm{~m})$. This borehole produces water at a depth of 60 $\mathrm{m}$ with a discharge of $1.8 \mathrm{~m}^{3}$ /hour. At a rate of $1.5 \mathrm{~m}^{3} /$ hour, a borewell can provide for ten households or approximately 40 people. The boring at T2D should continue to reach deeper than $70 \mathrm{~m}$ where marly limestone and sand prevail and potentially produce a discharge of $15 \mathrm{~m}^{3} /$ hour. At this rate, the well would be able to meet the water needs of 250 households or around 1,000 people.

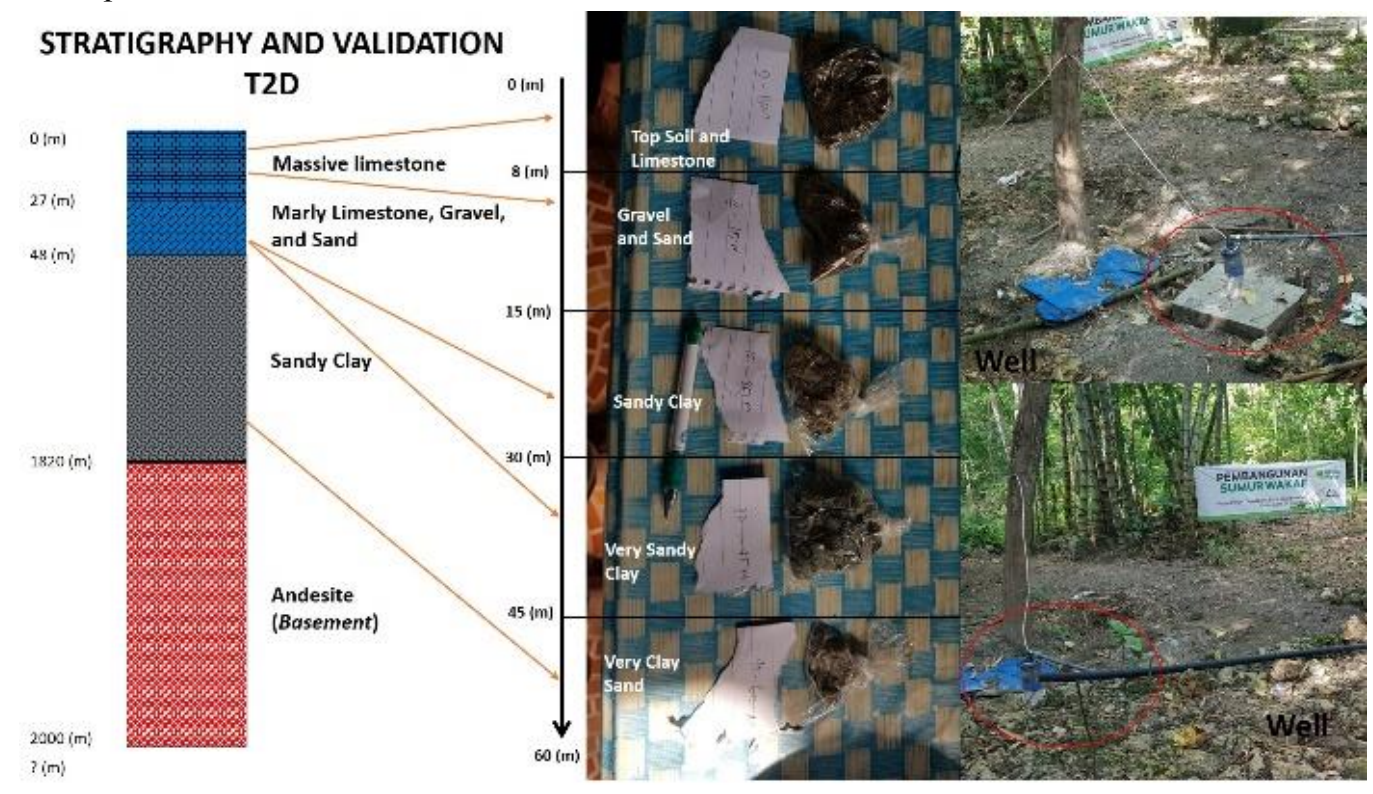

Fig. 4. Stratigraphy of T2D 


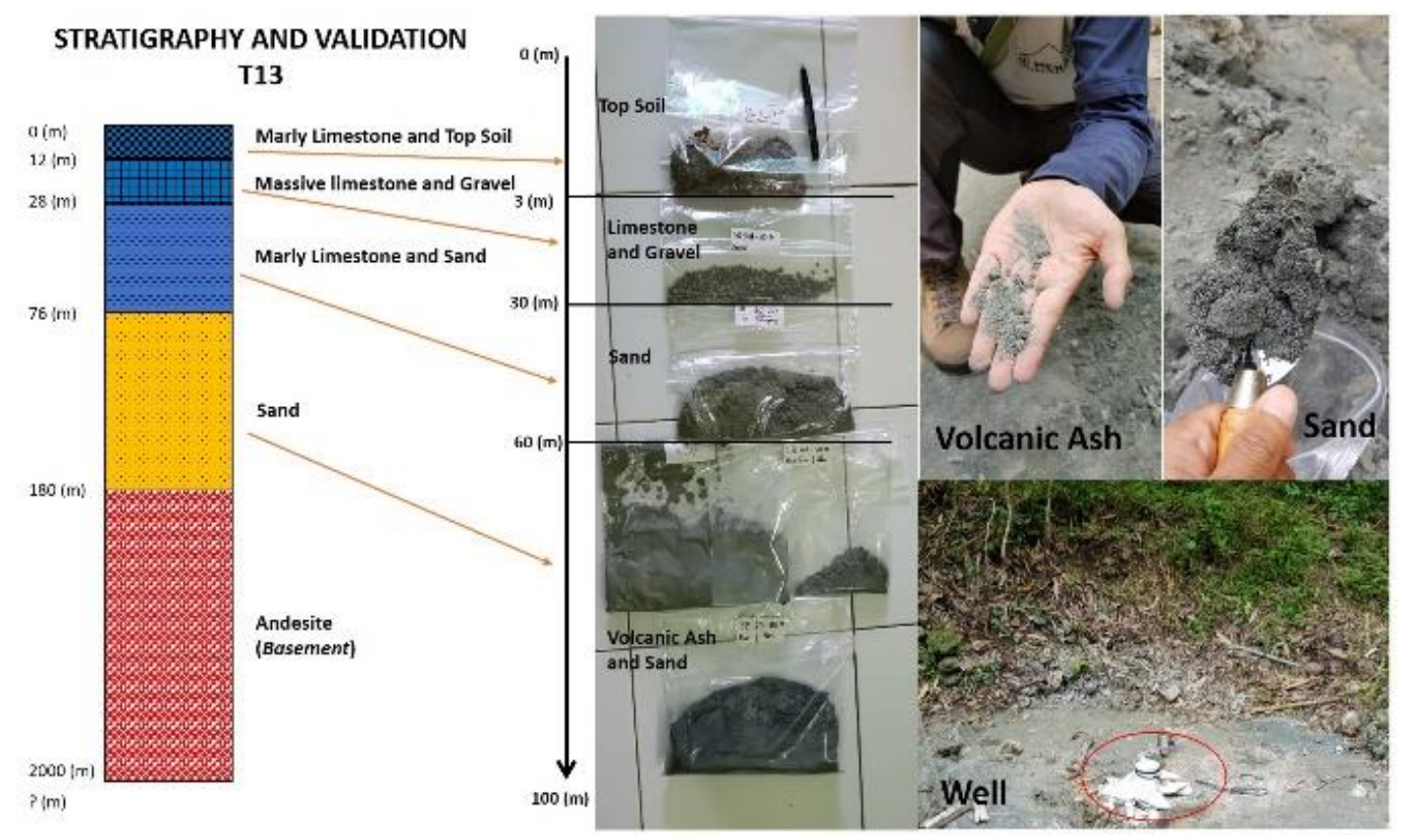

Fig. 5. Stratigraphy of T13

T13 is the second bore well-financed by another private party. Validation with VLF at this point $(100 \mathrm{~m}$ deep borehole; Figure 5) confirmed that the rods reading was accurate. This point is composed of topsoil and marly limestone $(0-3 \mathrm{~m})$, massive limestone and gravel $(3-30 \mathrm{~m})$, marly limestone and sand $(30-60 \mathrm{~m})$, and volcanic ash and sand $(60-100 \mathrm{~m})$. The volcanic ash and sand originated from the activity of an ancient volcano called Parangtritis-Imogiri along the southern belt during the Early Miocene or around 26.5 million years ago [18]. The material below the Wonosari Formation (Tmwl) is the Nglanggran Formation (Tmn), comprising volcanic breccia, flow breccia, agglomerate, lava, and tuff that were deposited during the Miocene Epoch [15]. The drilling at T13 discovered water at a depth of $100 \mathrm{~m}$ with a discharge of $19 \mathrm{~m}^{3} /$ hour. At $13 \mathrm{~m}^{3} /$ hour, a water well can provide for 280 households or around 960 people. However, the boring should be carried out until it reached deeper than $76 \mathrm{~m}$ where the material is dominated by sand and can produce up to $19 \mathrm{~m}^{3} /$ hour to fulfill the needs of 300 households or approximately 1,200 people.

T22D is a well bored independently by the villagers before the installation of the three wells above. At this well, the water emerges at a depth of $60 \mathrm{~m}$, but it can only provide for five households or 20 people-a rather minimum yield for a borehole. The results of VLF validated and confirmed the results of the dowsing at this point (60m deep borehole; Figure 6).

\section{STRATIGRAPHY AND VALIDATION T22 D}

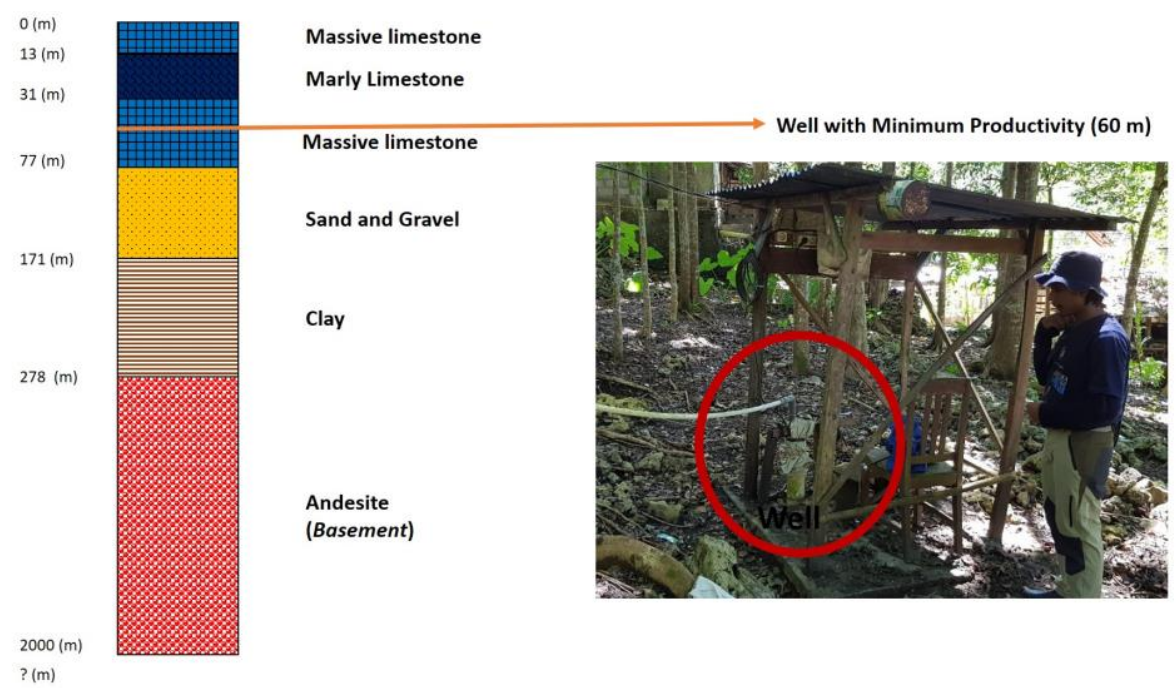

Fig. 6. Stratigraphy T22D 
The material present at this depth is massive limestone that can produce a discharge of $1.5 \mathrm{~m}^{3} /$ hour, which is categorically small to meet the needs of four households or 20 people. The results of both geophysical method and the calculation of water need are in line with the conditions in the field. T22D requires well sinking to raise the amount of the extractable water. Descending the well's foundation to $77-171 \mathrm{~m}$ (sands) can increase the discharge up to $27 \mathrm{~m}^{3} /$ hour. The sands are the product of ancient volcanic activity. Possessing a discharge potential of $27 \mathrm{~m}^{3} /$ hour, a well is likely to produce water for 500 households or around 2,000 people.

\section{Conclusion}

The installation of deep borewell is proposed as an alternative water source in Panggang Subsystem, a hydrogeology block. For a productive well, the drilling needs to reach volcanic materials like sand or ash underneath the limestone layer. The recommended depth of the borehole is where the tertiary volcanic aquifer layer is located, as detected from the VLF measurements in Panggang Block. Sands in tertiary volcanic aquifers has sizeable discharge to meet the water needs of the community; hence, the selection of this material for a prospective borewell. The technical problem in drilling deep well is the presence of limestone, which requires drilling equipment with a high specification that can penetrate the thick and hard reef limestone to reach the desired aquifer.

This research is part of the first author's thesis at the Master Program on Planning and Management of Coastal Area and Watershed, Faculty of Geography, Universitas Gadjah Mada, Indonesia. It received financial assistance from Research Grant fund under the scheme of Final Assignment Recognition Grant (Hibah Rekognisi Tugas Akhir, RTA) managed by Universitas Gadjah Mada in 2019 with the title "Characterization of the Hydrological System of Gunungsewu and Jonggrangan Karst Areas as a Model for Sustainable Water Resources management in Tropical Karst."

\section{Reference}

1. E. Hayono, D.H. Barianto, A. Cahyadi, Hydrogeology of the Gunungsewu Karst Region: The 2nd PIT PAAI Fieldtrip Field Guide, Yogyakarta: Perhimpunan Ahli Airtanah Indonesia (PAAI) (2017)

2. E. Haryono, Introduction to Gunungsewu Karst. Field Guide of Asian Trans-Disciplinary Karst Conference, Yogyakarta: Karst Research Group, Faculty of Geogrpahy - Gadjah Mada University (2011)

3. A. Cahyadi, I.A. Riyanto, T.N. Adji, T.A. Tivianton, R.A. Agniy, F. Ramadhan, M. Naufal, T.C. Saputro, Hydrostratigraphy and Its Impact on the Emergence of Springs in the Roast Sub-System, Gunungsewu Karst Region, Gunungkidul Regency, Proceedings of Seminar Nasional Geografi II organized by
Himpunan Mahasiswa Pascasarjana Geografi (HMPG) UGM (2018)

4. I.A. Riyanto, A. Cahyadi, T.N. Adji, E. Haryono, M. Widyastuti, R.F. Agniy, W.A. Fathoni, N. Rahmawati, H. Baskoro, The Analysis of Connectivity and Characterization of Pelorongan by Tracing Tests on Epicarst Springs of Roast Subsystems Gunungsewu Karst Region, Proceedings of the Annual Scientific Week organized by Perhimpunan Ahli Airtanah Indonesia (PAAI) (2018)

5. S.B. Kusumayudha, Detecting Springs in the Coastal Area of the Gunungsewu Karst Terrain, Yogyakarta Special Province, Indonesia, using Fractal Geometry Analysis, The Journal of Technology and Science 2(4), 1 - 12 (2009)

6. S. Soetrisno, The 1: 250.000 Hydrogeological Map of Indonesia, Sheet Yogyakarta (Java), Bandung: Directorate of Environmental Geology (1982)

7. N. Rahmawati, Characterization of Karst Aquifers based on Flow and Debit Response Properties of Guntur, Girijati, Purwosari, Gunungkidul, DIY Springs (Bachelor Thesis), Yogyakarta: Faculty of Geography UGM (2019)

8. M. Widyastuti, I.A. Riyanto, M. Naufal, F. Ramadhan, N. Rahmawati, Water Catchement Area Analysis of Guntur Karst Spring, The Second International Conference on Environmental Resources Management in Global Region, Yogyakarta: Universitas Gadjah Mada 256 (2019)

9. A. Cahyadi, The Role of Lake in Fulfilling the Water Needs of the Gunungsewu Karst Area After the Construction of the Clean Water Network, Geomedia 14(2), 23-33 (2016)

10. H. Fatchurohman, A. Cahyadi, H. Nugraha, D. Wacano, Strategy for Community Adaptation to Drought Disasters in the Karst District of Panggang District, Gunungkidul Regency, Deepublish (2013).

11. A. Cahyadi, The Level of Community Knowledge of Existence and Causes of Damage to Underground River Water Resources in the Gunungsewu Karst Area, Geomedia 11(2), 253-260 (2013)

12. A. Brunsch, T.N. Adji, D. Stoffe, M. Ikhwan, P. Oberle, F. Nestmann, Hydrological Assessment of a Karst Area in Southern Java with Respect to Climate Phenomena, Asian Trans-Disciplinary Karst Conference Yogyakarta-Indonesia (2011)

13. Regional Ordinance of Kabupaten Gunungkidul No. 6 about Spatial Plan 2010-2030 (2010)

14. B.P. Statistik, Gunung Kidul Regency in Numbers, BPS (2018)

15. W. Rahardjo, Sukandarrumidi, H.M.D. Rosidi, Geological Map of The Yogyakarta Sheet, Java scale 1: 100.000, Bandung: Geological Research and Development Centre (1995)

16. G. Hartono, Tertiary Volcano Study: Distribution of Eruption and Petrology Centers in the Southern 
Mountains of Yogyakarta (Master Thesis), Bandung: Bandung Institute of Technology (2000)

17. G. Hartono, S. Bronto, The origins of the formation of Mount Batur in the Wediombo area, Gunungkidul, Yogyakarta, Jurnal Geologi Indonesia 2(3), 143-158 (2007)

18. S. Bronto, Geology of Ancient Volcanoes, Bandung: Badan Geologi Kementerian Energi dan Sumber Daya Mineral (2010)

19. Sunarto, M.A. Marfai, T. Gunawan, S.G. Murti, A. Cahyadi, H. Fatchurohman, M.N. Malawani, Characteristics of Parangtritis Coastal Area Aquifers, Bantul Regency, Proceedings of the National Geography Seminar I Gadjah Mada University (2017) 